\title{
Pengaruh Sosialisasi, Kualitas Pelayanan, Sanksi dan Biaya Kepatuhan Pada Tingkat Kepatuhan Wajib Pajak Kendaraan Bermotor
}

\author{
Ni Komang Ayu Puspita Dewi ${ }^{1}$ \\ I Ketut Jati ${ }^{2}$ \\ ${ }^{1}$ Fakultas Ekonomi dan Bisnis Universitas Udayana (Unud), Bali, Indonesia \\ email: ayupuspita316@gmail.com/telp: +6283846920907 \\ ${ }^{2}$ Fakultas Ekonomi dan Bisnis Universitas Udayana (Unud), Bali, Indonesia
}

\begin{abstract}
ABSTRAK
Kepatuhan wajib pajak merupakan suatu keadaan dimana sesuai dengan UndangUndang yang berlaku wajib pajak harus memenuhi kewajiban dan hak perpajakannya. Penelitian ini memiliki tujuan menguji dan memperoleh buktiapakah sosialisasi, kualitas pelayanan, sanksi perpajakan, dan biaya kepatuhan memiliki pengaruh pada tingkat kepatuhan wajib pajak kendaraan bermotor. Penelitian dilakukan di Kantor Bersama SAMSAT Klungkung. Metode accidental sampling merupakan metodeyang digunakan untuk menentukan sampel yang akan digunakan dengan ukuran sampel yang dihitung berdasarkan rumus Slovin. Pengumpulan data dilakukan dengan teknik wawancara dan menyebarkan lembar kuesioner ke 100 responden. Analisis Regresi Linier Berganda merupakan teknik yang dipergunakan pada penelitian ini.Penelitian ini memberikan hasil variabel sosialisasi, kualitas pelayanan, dan sanksi perpajakan mempunyai pengaruh positif dan signifikan pada kepatuhan wajib pajak kendaraan bermotor, namun variabel biaya kepatuhan memiliki pengaruh negatif terhadap tingkat kepatuhan wajib pajak kendaraan bermotor.

Kata kunci: Sosialisasi perpajakan, kualitas pelayanan, sanksi perpajakan, biaya kepatuhan, kepatuhan wajib pajak
\end{abstract}

\begin{abstract}
Tax compliance is a situation where in accordance with the applicable law must meet the obligations of taxpayers and taxation rights. This research has the goal to test and obtain proof of whether socialization, quality of service, tax penalties, and compliance costs have an impact on the level of tax compliance vehicles. The study was conducted at the Joint Office SAMSAT Klungkung. Accidental sampling is a methodwhich is used to determine the sample that will be used by the sample size was calculated based on the Slovin formula. Data was collected by interview and questionnaire to 100 respondents. Regression analysis is a technique used in this study. This study gives the results of socialization, quality of service, and tax penalties have a positive and significant impact on taxpayer compliance motor vehicle, but the variable cost of compliance has a negative effect on the rate of motor vehicle tax compliance.
\end{abstract}

Keywords: Socialization taxation, quality of service, tax penalties, compliance costs, compliance taxpayer 
Ni Komang Ayu Puspita Dewi danl Ketut Jati. Pengaruh ...

\section{PENDAHULUAN}

Ada beberapa jenis pajak provinsi yang merupakan bagian dari pajak daerah yaitu Pajak Bahan Bakar Kendaraan Bermotor, Pajak Air Permukaan dan Pajak Rokok, Pajak Kendaraan Bermotor (PKB), Bea Balik Nama Kendaraan Bermotor (BBNKB) (Undang-Undang Nomor 28 Tahun 2009). PKB adalah satu-satunya pajak daerah yang membiayai pembangunan daerah provinsi. PKB ditangani Kantor Bersama SAMSAT (Sistem Administrasi Manunggal dibawah Satu Atap) di bawah naungan kantor Dispenda (Kantor Dinas Pendapatan Daerah).

Pajak kendaraan bermotor yang diterima pada suatu daerah semakin meningkat setiap tahunnya semestinya bersamaan dengan meningkatnya kepatuhan membayar pajak kendaraan bermotor yang dilakukan oleh wajib pajak. Namun kenyataannyaupaya yang dilakukan wajib pajak agar tangungan pajak tidak terlalu besardan kesadaran wajib pajak untuk melakukan kewajibannya masih sangat rendah. Kepatuhan pajak merupakan suatu keadaan dimana wajib pajak memenuhi semua kewajiban perpajakan dan melaksanakan hak perpajakannya (Winerungan, 2013). Kepatuhan pajak yang tidak meningkat akan mengancam upaya pemerintah untuk meningkatkan kesejahteraan masyarakat (Gerald, 2009).

Torgler (2005) menyebutkan bahwa pemasalahan yang sangat serius dan sangat berat dihadapi bagi yang membuat kebijakan ekonomi yaitu memberikan motivasi dan dorongan untuk wajib pajak agar mematuhi peraturan perpajakan. Salah satu faktor yang mempengaruhi tingkat kepatuhan wajib pajak adalah sosialisasi perpajakan yang dapat digunakan untuk berbagi informasi baik berupa 
informasi mengenai perpajakan dengan tujuanmenumbuhkan tingkat kesadaran dan rasa percaya masyarakat (yang dipungut) kepada pemerintah (yang dipungut) untuk mengelola apa yang sudah mereka lapor dan setorkan. Apabila sosialisasi perpajakan jarang dilakukan maka wawasan masyarakat mengenaiperpajakan dan tingkat rasa sadar masyarakat untuk membayar dan melaporkan perpajakan rendah serta membuat wajib pajakuntuk meningkatkan kepatuhan juga rendah (Winerungan, 2013).

Rendahnya kepatuhan pajak dapat disebabkan oleh kurangnya kualitas pelayanan petugas pajak. Seorang wajib pajak akan cenderung melaksanakan kewajiban perpajakannya sesuai dengan aturan dan ketentuan yang berlakuapabila mendapatkan pelayanan yang baik dari petugas pajak (Anggraeni, 2013). Perasaan puas dan senang atas pelayanan yang diberikan oleh pemerintah dapat membuat wajib pajak termotivasi untuk melaksanakan kepatuhan dan akhirnya dapat meningkatkan pendapatan asli daerah (Palda dan Hanousek, 2002).

Sanksi pajak dengan tujuan agar wajib pajak takut untuk melanggar Undang-Undang Perpajakan. Sebagian besar kepatuhan pajak dipusatkan pada bagaimana pendeteksian dan sanksi dapat menghalangi penghindaran pajak (Franzoni, 1998). Apabila tidak adanya ketegasan dari instansi perpajakan maka ketidakpatuhan wajib pajak dalam melaksanakan self assesment system dapat berkembang. Sanksi yang tegas harus diberlakukan untuk mendorong wajib pajak agar memenuhi kewajiban perpajakannya dan mencegah ketidakpatuhan, dalam rangka untuk memajukan efektivitas sistem pajak dan keadilan. 
Ni Komang Ayu Puspita Dewi danl Ketut Jati. Pengaruh ...

Biaya kepatuhan perpajakan adalah biaya yang memang harus dibayarkan dalam melakukan perpajakannyaoleh wajib pajak (Susmita, 2015). Peraturan perpajakan yang kompleks membuat wajib pajak akan mengorbankan waktu dan biaya yang tidak sedikit untuk urusan pajak karena mendapat kesulitan untuk memenuhi kewajiban pajaknya. Wajib pajak lebih mengarahpada tindakan ketidakpatuhan pajak seperti penggelapan pajak ataupunpenghindaran apabila biaya kepatuhan yang dikorbankan oleh wajib pajak semakin besar.

Penelitian ini dilakukan di Kantor Bersama SAMSAT Klungkung yang merupakan tempat para wajib pajakdalam membayar pajak untuk kendaraan bermotornya. Jumlah kendaraan bermotor di kabupaten Klungkung dari tahun ke tahun mengalami peningkatan sehingga menyebabkan semakin meningkatnya pula jumlah wajib pajak kendaraan bermotor. Tabel 1 memperlihatkan jumlah kendaraan bermotor yang terdaftar di Kabupaten Klungkung tahun 2012-2016.

Tabel 1.

Jumlah Kendaraan Bermotor yang Terdaftar di Kantor Bersama SAMSAT Klungkung Tahun 2012-2016

\begin{tabular}{|c|c|c|c|c|c|c|}
\hline \multirow[t]{2}{*}{ No } & \multirow[t]{2}{*}{$\begin{array}{c}\text { Jenis } \\
\text { Kendaraan } \\
\end{array}$} & \multicolumn{5}{|c|}{ Tahun } \\
\hline & & 2012 & 2013 & 2014 & 2015 & 2016 \\
\hline 1 & Sedan & 491 & 506 & 494 & 510 & 527 \\
\hline 2 & Jeep & 701 & 741 & 715 & 752 & 785 \\
\hline 3 & Minibus & 3.804 & 4.374 & 5.030 & 5.713 & 6.385 \\
\hline 4 & Bus & 123 & 131 & 117 & 118 & 121 \\
\hline 5 & Pickup & 2.327 & 2.601 & 2.728 & 3.111 & 3.430 \\
\hline 6 & Truck & 1.467 & 1.675 & 1.589 & 1.663 & 1.716 \\
\hline \multirow[t]{2}{*}{7} & Sepeda Motor & 70.439 & 77.945 & 86.282 & 93.701 & 100.277 \\
\hline & Jumlah (unit) & 79.352 & 87.973 & 96.955 & 105.568 & 113.241 \\
\hline \multicolumn{2}{|c|}{$\begin{array}{c}\text { Rata-rata Pertumbuhan } \\
(\%)\end{array}$} & - & 11 & 10 & 9 & 7 \\
\hline
\end{tabular}


Berdasarkan Tabel 1 diketahui bahwa jumlah kendaraan bermotor yang terdaftar di Kantor Bersama SAMSAT Klungkung dari tahun 2012 mengalami peningkatan pada tahun 2013 sebesar 11 persen, 10 persen pada tahun 2014, pada tahun 2015 juga meningkat yaitu sebesar 9 persen dan pada tahun 2016 sebesar 7 persen. Faktor yang menyebabkan sehingga jumlah kendaraan bermotor meningkat setiap tahunnya diantaranya, semakin meningkatnyakebutuhan seseorang terhadap alat transportasi, tingginya daya beli masyarakat, semakin banyak cicilan dengan bunga ringan yang diberikan oleh para dealer dan sangat mudahnya syarat untuk memiliki kendaraan bermotor.

Meningkatnya jumlah kendaraan bermotor dari tahun ke tahun tidak sejalan dengan kepatuhan wajib untuk melakukan pembayaran pajak kendaraan bermotor. Kepatuhan wajib pajak yang rendah dapat dilihat dari jumlah denda yang diterima oleh wajib pajak kendaraan bermotor yang diakibatkan karena ketidak tepat waktu mereka dalam membayar pajak. Pada Tabel 2 disajikan jumlah pokok penerimaan, obyek kendaraan yang sudahmelakukan kewajibanya dalam perpajakan, dan denda di Kantor Bersama SAMSAT Klungkung tahun 2012-2016.

Tabel 2.

Jumlah Obyek Kendaraan yang SudahMelakukan Kewajiban Pajak, Pokok Penerimaan dan Denda di Kantor Bersama SAMSAT Klungkung Tahun 2012-2016

\begin{tabular}{llllll}
\hline No & Tahun & $\begin{array}{l}\text { Jumlah } \\
\text { (unit) }\end{array}$ & Pokok (Rp) & Denda (Rp) & Jumlah (Rp) \\
\hline 1 & 2012 & 59.391 & 15.202 .198 .550 & 682.940 .500 & 15.885 .139 .050 \\
2 & 2013 & 64.742 & 18.276 .543 .100 & 566.934 .200 & 18.843 .477 .300 \\
3 & 2014 & 68.579 & 20.838 .289 .600 & 948.467 .300 & 21.786 .756 .900 \\
4 & 2015 & 70.450 & 51.920 .838 .500 & 1.331 .344 .200 & 53.252 .182 .700 \\
5 & 2016 & 72.512 & 55.924 .724 .881 & 774.103 .202 & 56.698 .828 .083 \\
\hline \multicolumn{5}{l}{ Sumber : Kantor Bersama SAMSAT Klungkung, 2017 }
\end{tabular}


Berdasarkan Tabel 2, kepatuhan para waijb pajak untuk memenuhi kewajibannya dalam melaksanakanpembayaran pajak kendaraan bermotor tidak diimbangi dengan pokok penerimaan pajak kendaraan bermotor semakin meningkat, hal tersebut terlihatpada jumlah denda yang cukup tinggi di Kantor Bersama SAMSAT Klungkung.

Banyak penelitian telah dilakukan terkait dengan tingkat kepatuhan wajib pajak, seperti penelitian dari Dharma (2014), Widnyani (2016) dan Trisnasari (2017) yangmendapatkan hasil bahwa variabel sosialisasi perpajakan terhadap kepatuhan wajib pajakberpengaruh positif. Penelitian yang dilakukan oleh Senja (2015),Pranata (2015)dan Febriyanti (2017)mendapatkan hasil bahwa kualitas pelayanan terhadap kepatuhan wajib pajakberpengaruh positif. Berbeda dengan hasil penelitian Novitasari (2015) yang menyatakan bahwa kualitas pelayanan terhadap kepatuhan wajib pajak dalam membayar pajak kendaraan bermotortidak berpengaruh secara parsial. Penelitian yang dilakukan oleh Paramartha (2015), Sari (2013) dan Sucahyani (2017) menyatakan bahwa sanksi perpajakan pada kepatuhan wajib pajakberpengaruh positif. Namun penelitian Irianingsih (2015) menyatakan bahwa sanksi perpajakan terhadap kepatuhan wajib pajaktidak berpengaruh. Penelitian Endaryanti (2017) dan Efendi (2015) menyatakan bahwa biaya kepatuhan berpengaruh negatif terhadap kepatuhan wajib pajak. Hasil penelitian Anggadewi (2015) menyatakan bahwa biaya kepatuhan terhadap kepatuhan wajib pajak berpengaruh secara signifikan.

Berdasarkan latar belakang yang telah diuraikan tersebut, maka peneliti tertarik untuk menguji kembali apakah sosialisasi, kualitas pelayanan, sanksi 
perpajakan dan biaya kepatuhan mempengaruhi tingkat kepatuhan wajib pajak kendaraan bermotor di Kantor Bersama SAMSAT Klungkung. Adanya kontradiksi dan ketidak konsistenan terhadap penelitian sebelumnya sehingga penelitian ini layak untuk diteliti kembali.

Tujuan yang ingin dicapai pada penelitian ini untuk membuktikan bahwa variabel sosialisasi, kualitas pelayanan, sanksi perpajakan, dan biaya kepatuhan mempengaruhi tingkat kepatuhan wajib pajak kendaraan bermotor. Harapan dari penelitian ini dapat memberi manfaat teoretis diantaranya memberikan pengembangan pengetahuan dalam ilmu perpajakan yang berkaitan dengan pengaruh sosialisasi, kualitas pelayanan, sanksi perpajakan, dan biaya kepatuhan terhadap kepatuhan wajib pajak dan dijadikan tambahan referensi bagi penelitian berikutnya, serta manfaat praktis untuk dapat memberikan masukan-masukan, sumbangan pemikiran dan bahan pertimbangan mengenai sosialisasi, kualitas pelayanan, sanksi perpajakan, dan biaya kepatuhan agar dapat menjadi bahan evaluasi di masa akan datang oleh pihak pembuat kebijakan perpajakan khususnya yang berhubungan dengan Pajak Kendaraan Bermotor (PKB).

Theory of Planned Behavior (TPB) merupakan teori yang digunakan dalam penelitian ini, Feld and Frey (2002) menyatakan penelitian mengenai kepatuhan pajak dapat dilihat dari sisi psikologi wajib pajak. Kajian dalam bidang psikologi mengenai faktor yang mempengaruhi perilaku kepatuhan pajak, salah satunya adalah melalui Theory of Planned Behavior (Ajzen, 1991). TPB menjelaskanbahwa perilaku individu untuk tidak patuh terhadap ketentuan perpajakan ditentukan oleh niat (intention) (Mustikasari, 2007).Niat untuk 
berperilaku dipengaruhi oleh tiga faktor yaitubehavioral beliefs, normative beliefs, dan control beliefs. Sikap yang mendorong perilaku merupakan derajat dimana seseorang memiliki evaluasi atau penilaian positif atau negatif terhadap perilaku yang akan ditampilkan. Respon positif dan negatif itu adalah hasil proses evaluasi terhadap keyakinan individu yang mendorong perilaku (Ajzen, 1991). Dikaitkan dengan penelitian ini, perilaku wajib pajak dalam memenuhi kewajiban perpajakannya dapat dijelaskan dalam theory of planned behavior.

Sosialisasi, kualitas pelayanan, sanksi perpajakan, dan biaya kepatuhan pajak dapat menjadi faktor yang menentukan perilaku patuh wajib pajak. Setelah termotivasi dengan mendapatkan sosialisasi mengenai perpajakan secara memadai, pelayanan yang berkualitas diberikan petugas dinas, adanya sanksi pajak yang dikenakan dan rendahnya biaya kepatuhan pajak juga dapat enggan untuk melanggar peraturan perpajakan, maka wajib pajak dapat meningkatkan kepatuhannya dalam memenuhi kewajibansebagai wajib pajakyang dikarenakan oleh niat wajib pajak untuk memenuhi kewajiban perpajakannya dan kemudian niat tersebut direalisasikan. 
Sosialisasi perpajakan dalam Theory of Planned Behavior merupakan faktor eksternalyang dapat memberikan pengaruh kepada perilaku wajib pajak untuk memenuhi kewajibannya. Sosialisasi perpajakan merupakan upaya dari Dinas Pendapatan Daerah untuk memberikan penjelasan, pembinaan berbagai informasi terbaru yang berhubungan dengan peraturan perpajakan. Pentingnya sosialisasiakan memberikan masyarakatpengertian dalam membayar pajak, danmasyarakat menjadi paham serta mengerti mengenai manfaat membayar pajak (Winerungan, 2013). Penelitian yang dilakukan Widnyani (2016) danCahyadi (2016) mendapatkan hasil bahwa penegaruh sosialisasi perpajakan terhadap kepatuhan wajib pajak yaitu berpengaruh positif. Berdasarkan uraian tersebut, maka dapat dikembangkan hipotesis sebagai berikut.

$\mathrm{H}_{1}$ : Sosialisasi perpajakan berpengaruh positif pada tingkat kepatuhan wajib pajak dalam membayar pajak kendaraan bermotor.

Berdasarkan Theory of Planned Behavior, kualitas pelayanan dari petugas pajakberkaitan dengan normative beliefs merupakan harapan yang diperkirakan seseorang atau lebih untuk memotivasi individu dan menerima perilaku tertentuagar mereka dipatuhi. Kepatuhan wajib pajak dalam melaksanakan kewajiban pajak akan meningkat apabila pelayanan yang didapat dari petugas pajak dapat memberikan rasa puas. Penelitian yang telah dilakukan olehMegawangi (2016)memperoleh hasil bahwa kualitas pelayanan memiliki pengaruh yang signifikan tehadap kepatuhan wajib pajak. Pada penelitian yang dilakukanRusmayani (2017) dan Dharma (2014) mengatakan bahwa pengaruh kualitas pelayanan terhadap kepatuhan wajib pajak adalah berpengaruh positif. Berdasarkan uraian tersebut, maka dapat dikembangkan hipotesis sebagai berikut. 
$\mathrm{H}_{2}$ : Kualitas Pelayanan berpengaruh positif pada tingkat kepatuhan wajib pajak dalam membayar Pajak Kendaraan Bermotor.

Berdasarkan Theory of Planned Behavior, sanksi perpajakan terkait dengan Control beliefs. Sanksi pajak dibuat untuk mendukung agar wajib pajak mematuhi peraturan perpajakan. Putri dan Jati (2012) menyatakan jika semakin berat dan tegas sanksi perpajakan akanmemberikan peningkatan terhadap kepatuhan wajib pajak. Hal ini memberikan bukti bahwa peningkatan kepatuhan wajib pajak bisa terjadi apabila sanksi yang diterapkan dari instansi cukup tegas serta dianggap tidak akan memberikan kerugian kepada wajib pajak. Berdasarkan penelitian Kusuma (2016), Cahyadi (2016) dan Putra (2017) yang menyatakan bahwa sanksi perpajakan berpengaruh secara signifikan terhadap kepatuhan wajib pajak. Berdasarkan uraian tersebut, maka dapat dikembangkan hipotesis sebagai berikut. $\mathrm{H}_{3}$ : Sanksi Perpajakan berpengaruh positif terhadap tingkat kepatuhan wajib pajak dalam membayar Pajak Kendaraan Bermotor.

Pada saat dilakukannya biaya kepatuhan wajib pajak, wajib pajak yang dikenakan biaya harus mengeluarkan sejumlah biaya. Wajib pajak enggan untuk membayar pajakkarena biaya kepatuhan pajak yang diterima terlalu tinggi, sehingga biaya kepatuhan bisa menjadi suatu hal yang mendorong atau menghambat keperilakuan seseorang. Jika Theory of Planned Behavior dihubungkan dengan biaya kepatuhan, seseorang akan lebihmengarah melakukan penggelapan pajak apabila tanggungan biayadari biaya kepatuhan sangat tinggi dan memberatkan wajib pajak. Hasil penelitian yang telah dilakukan oleh Fuadi (2013) dan Susmita (2015) mengatakan bahwa biaya kepatuhan perpajakan 
berpengaruh negatif terhadap tingkat kepatuhan wajib pajak. Berdasarkan uraian tersebut, maka dapat dikembangkan hipotesis sebagai berikut.

$\mathrm{H}_{4}$ : Biaya Kepatuhan berpengaruh negatif pada tingkat kepatuhan wajib pajak dalam membayar Pajak Kendaraan Bermotor.

\section{METODE PENELITIAN}

Penelitian ini menggunakan pendeketan kuantitatif berbentuk asosiatif yaitu dimana penelitian bertujuan untuk mengetahui hubungan dari dua variabel atau lebih. Dalam penelitian ini jenis hubungannya adalah hubungan linier karena bertujuan untuk mengetahui variabel-variabel bebas $(\mathrm{X})$ terhadap variabel terikat (Y). Lokasi dilakukannya penelitian ini adalah di Kantor Bersama SAMSAT Klungkung yang berada di Jalan Ngurah Rai No 3 Semarapura Klungkung. Dipilihnya lokasi penelitian ini di Kantor Bersama SAMSAT Klungkung karena kantor ini merupakan kantor untuk melakukan kepatuhan wajib pajak PKB di Kota Klungkung. Berdasarkan tabel 2 menunjukkan bahwa di Kantor Bersama SAMSAT Klungkung tingkat wajib pajak PKB untuk patuh pada pemenuhan kewajibannya masih kurang sehingga tunggakan PKB masih banyak. Hal tersebut membuat peneliti tertarik untuk meneliti faktor-faktor yang mempengaruhi kepatuhan wajib pajak khususnya PKB.

Obyek penelitian disini adalah wajib pajak yang patuh dalam melaksanakan pembayaran Pajak Kendaraan Bermotor (PKB) di Kantor Bersama SAMSAT Klungkung yang dijabarkan oleh variabel sosialisasi, kualitas pelayanan, sanksi perpajakan, dan biaya kepatuhan. Variabel dependen yang digunakanpada penelitian ini adalah Kepatuhan Wajib Pajak (Y), pada penelitian ini 
menggunakan variabel independen yaitu Sosialisasi $\left(\mathrm{X}_{1}\right)$, Kualitas Pelayanan $\left(\mathrm{X}_{2}\right)$, Sanksi Perpajakan $\left(\mathrm{X}_{3}\right)$, dan Biaya Kepatuhan $\left(\mathrm{X}_{4}\right)$.

Penelitian ini menggunakan populasi yaitu seluruh Wajib Pajak Kendaraan Bermotor yang ada dan sudah terdaftar pada Kantor Bersama SAMSAT Klungkung. Penelitian menggunakan sampel yaitu seluruh responden yang memenuhi kriteria sebagai sampel. Dimana kriteria yang dijadikan responden pada penelitian ini adalah responden yang merupakan Wajib Pajak Kendaraan Bermotor yang terdaftar di Kantor Bersama SAMSAT Klungkung.

Metode accidental samplingmerupakan metode yang digunakan pada penentuan sampel pada penelitian ini dimana metode ini adalah teknik dalam menentukan sampel yang berdasarkan kebetulan, yaitu wajib pajak yang bertemu dengan penelitisecara kebetulandan apabila dipandang cocok sebagai sumber data dan memenuhi kriteria sebagai responden merupakan wajib pajak yang terdaftar di Kantor Bersama SAMSAT Klungkung, melakukan pembayaran pajak kendaraan bermotor, dan status kepemilikan kendaraan bersifat pribadi kecuali untuk umur di bawah 26 tahun status kepemilikan masih dari orangtua bisa maka bisa digunakan sebagai sampel. Besarnya suatu sampel dihitung dengan rumus Slovin yaitu sebagai berikut.

$$
n=\frac{N}{1+\mathrm{Ne}^{2}}
$$

Keterangan:

$\mathrm{N}=$ Jumlah populasi

$\mathrm{n}=$ jumlah sampel

$\mathrm{e}=$ Nilai kritis, yaitu 0,1 
Perhitungan sampel:

$$
\begin{aligned}
& \mathrm{n}=\frac{72.512}{\left(1+72.512(0,1)^{2}\right)} \\
& \mathrm{n}=99,86 \\
& \mathrm{n}=100 \text { (dibulatkan) }
\end{aligned}
$$

Berdasarkan perhitungan di atas, didapat 100 wajib pajak kendaraan bermotor di Kantor Bersama SAMSAT Klungkung yang merupakan sampel yang dapat dipergunakan pada penelitian ini.

Pengumpulan data pada penelitian ini menggunakan metode kuisioner yangdibawakan ke tempat dilakukannya penelitian dan langsung diberikan pada beberapa responden. Pada metode ini akan memperoleh data berupa hasil kuisioneryang telah diisi wajib pajak kendaraan bermotor yangberupa jawaban dari pernyataan seputar variabel yang diteliti. Jawaban-jawaban responden diberi nilai/skor menggunakan skala Likert 1 sampai 4.

Jenis data yang digunakan pada penelitian ini ada dua yaitu data kuantitatif dan data kualitatif (Sugiyono, 2017:7). Data kuantitatif yang digunakan dalam penelitian ini adalah data jumlah kendaraan bermotor yang terdaftar di Kantor Bersama SAMSAT Klungkung, jumlah obyek kendaraan yang melaksanakan kewajiban perpajakan, denda serta pokok penerimaan di Kantor Bersama SAMSAT Klungkung serta hasil kuisioner yang berupa jawaban dari responden. Pada penelitian ini menggunakan data kualitatif yaitusejarah berdirinya Kantor Bersama SAMSAT Klungkung dan struktur organisasi di Kantor Bersama SAMSAT Klungkung. 
Penelitian ini menggunakan dua sumber data yaitu data sekunder dan data primer (Sugiyono, 2017:137). Data primer pada penelitian ini didapat dari jawaban-jawaban hasil pengisian kuesioner sedangkan data sekunder pada penelitian ini didapat dari data mengenai jumlah kendaraan bermotor yang terdaftar di Kantor Bersama SAMSAT Klungkung, jumlah obyek kendaraan yang telah melakukan kewajiban perpajakannya, jumlah denda serta pokok penerimaan pajak kendaraan bermotor di Kantor Bersama SAMSAT Klungkung.

\section{HASIL DAN PEMBAHASAN}

Statistik deskriptif dalam penelitian ini disajikan untuk memberikan informasi tentang karakteristik variabel penelitian, antara lain minimum, maksimum, mean, standar deviasi. Informasi mengenai hasil statistik deskriptif dapat dilihat pada Tabel 3 berikut.

Tabel 3.

Hasil Uji Statistik Deskriptif

\begin{tabular}{lrrrrr}
\hline Variabel & N & Minimum & Maximum & Mean & Std. Deviation \\
\hline Sosialisasi Perpajakan (X1) & 100 & 9 & 18 & 13,65 & 1,99 \\
Kualitas Pelayanan (X2) & 100 & 37 & 72 & 59,29 & 8,77 \\
Sanksi Perpajakan (X3) & 100 & 10 & 16 & 13,77 & 1,85 \\
Biaya Kepatuhan (X4) & 100 & 7 & 19 & 10,58 & 1,73 \\
Kepatuhan Wajib Pajak (Y) & 100 & 10 & 16 & 13,64 & 1,52 \\
\hline Valid N (listwise) & 100 & & & &
\end{tabular}

Berdasarkan Tabel 3 terlihat bahwa pegamatan $(\mathrm{N})$ dalam penelitian ini berjumlah 100 kuesioner.Variabel sosialisasi perpajakan memiliki nilai minimum 9 dan maksimum 18, dengan nilai rata-rata sebesar 13,65 menunjukkan bahwa wajib pajak merasakan sosialisasi perpajakan dapat mendorong tingkat kepatuhan wajib pajak. Standar deviasi sebesar 1,99 menunjukkan bahwa standar 
penyimpangan data terhadap nilai rata-ratanya adalah 1,99. Variabel kedua yaitu kualitas pelayanan memiliki nilai minimum 37 dan nilai maksimum 72 dengan nilai rata-rata sebesar 59,29 yang menunjukkan bahwa kualitas pelayanan dapat meningkatkan tingkat kepatuhan wajib pajak. Standar deviasi sebesar 8,77 menunjukkan bahwa standar penyimpangan data terhadap nilai rata-ratanya adalah 8,77. Variabel ketiga yaitu sanksi perpajakan memiliki nilai minimum 10 dan nilai maksimum 16 dengan nilai rata-rata sebesar 13,77 yang menunjukkan bahwa dengan adanya sanksi perpajakan maka wajib pajak akan enggan untuk melanggar kewajiban pajaknya. Standar deviasi sebesar 1,85 yang menunjukkan bahwa standar penyimpangan data terhadap nilai rata-ratanya sebesar 1,85 . Variabel keempat yaitu biaya kepatuhan memiliki nilai minimum 7 dan nilai maksimum 19 dengan nilai rata-rata sebesar 10,58 yang menunjukkan bahwa biaya kepatuhan perpajakan tidak terlalu mempengaruhi tingkat kepatuhan wajib pajak. Variabel dependen yaitu kepatuhan wajib pajak memiliki nilai minimum 10 dan nilai maksimum 16 dengan nilai rata-rata sebesar 13,64. Standar deviasinya 1,52 yang artinya bahwa standar penyimpangan data terhadap nilai rata-ratanya sebesar 1,52 .

Uji validitas digunakan untuk mengukur suatu kuesioner tersebut sah/valid atau tidak. Syarat minimum suatu kuesioner yang memenuhi validitas adalah jika antara skor totaldengan skor tiap pernyataan tersebut korelasinya (pearson correlation) lebih besar dari 0,30 dan positif (Sugiyono, 2017;125). Hasil uji validitas pada penelitian ini disajikan pada Tabel 4 berikut. 
Ni Komang Ayu Puspita Dewi danl Ketut Jati. Pengaruh ...

Tabel 4.

Hasil Uji Validitas

\begin{tabular}{|c|c|c|c|}
\hline Variabel & Item & Koefisien Korelasi & Keterangan \\
\hline \multirow[t]{4}{*}{ Kepatuhan Wajib Pajak (Y) } & Y.1 & 0,717 & Valid \\
\hline & Y.2 & 0,836 & Valid \\
\hline & Y.3 & 0,826 & Valid \\
\hline & Y.4 & 0,825 & Valid \\
\hline \multirow[t]{5}{*}{ Sosialisasi Perpajakan (X1) } & $\mathrm{X} 1.1$ & 0,806 & Valid \\
\hline & $\mathrm{X} 1.2$ & 0,817 & Valid \\
\hline & $\mathrm{X} 1.3$ & 0,746 & Valid \\
\hline & $\mathrm{X} 1.4$ & 0,754 & Valid \\
\hline & $\mathrm{X} 1.5$ & 0,761 & Valid \\
\hline \multirow[t]{18}{*}{ Kualitas Pelayanan (X2) } & $\mathrm{X} 2.1$ & 0,678 & Valid \\
\hline & $\mathrm{X} 2.2$ & 0,782 & Valid \\
\hline & $\mathrm{X} 2.3$ & 0,821 & Valid \\
\hline & $\mathrm{X} 2.4$ & 0,731 & Valid \\
\hline & $\mathrm{X} 2.5$ & 0,760 & Valid \\
\hline & $\mathrm{X} 2.6$ & 0,751 & Valid \\
\hline & $\mathrm{X} 2.7$ & 0,815 & Valid \\
\hline & $\mathrm{X} 2.8$ & 0,713 & Valid \\
\hline & $\mathrm{X} 2.9$ & 0,599 & Valid \\
\hline & $\mathrm{X} 2.10$ & 0,806 & Valid \\
\hline & $\mathrm{X} 2.11$ & 0,772 & Valid \\
\hline & $\mathrm{X} 2.12$ & 0,773 & Valid \\
\hline & $\mathrm{X} 2.13$ & 0,853 & Valid \\
\hline & $\mathrm{X} 2.14$ & 0,755 & Valid \\
\hline & $\mathrm{X} 2.15$ & 0,668 & Valid \\
\hline & $\mathrm{X} 2.16$ & 0,739 & Valid \\
\hline & $\mathrm{X} 2.17$ & 0,842 & Valid \\
\hline & $\mathrm{X} 2.18$ & 0,846 & Valid \\
\hline \multirow[t]{4}{*}{ Sanksi Perpajakan (X3) } & X3.1 & 0,699 & Valid \\
\hline & X3.2 & 0,710 & Valid \\
\hline & $\mathrm{X} 3.3$ & 0,878 & Valid \\
\hline & X3.4 & 0,821 & Valid \\
\hline \multirow[t]{5}{*}{ Biaya Kepatuhan (X4) } & $\mathrm{X} 4.1$ & 0,791 & Valid \\
\hline & $\mathrm{X} 4.2$ & 0,840 & Valid \\
\hline & $\mathrm{X} 4.3$ & 0,852 & Valid \\
\hline & $\mathrm{X} 4.4$ & 0,797 & Valid \\
\hline & $\mathrm{X} 4.5$ & 0,690 & Valid \\
\hline
\end{tabular}

Sumber:Data diolah, 2018 
Berdasarkan Tabel 4 diketahui bahwa seluruh indikator pernyataan dalam variabel sosialisasi perpajakan, kualitas pelayanan, sanksi perpajakan dan biaya kepatuhan memenuhi syarat validitas karena nilai korelasi antara skor tiap pernyataan dengan skor total menunjukkan hasil yang signifikan bernilai positif dan nilainya lebih dari 0,30 .

Suatu kuesioner dikatakan reliabel atau handal jika jawaban seseorang terhadap pernyataan adalah konsisten atau stabil dari waktu ke waktu dan memberikan nilai Cronbach's Alpha $(\alpha)>0,60$ (Sugiyono, 2017:130).Pada penelitian ini mendapatakan hasil uji reliabilitas yang disajikan pada Tabel 5 berikut.

Tabel 5. Hasil Uji Reliabilitas

\begin{tabular}{lcc}
\hline \multicolumn{1}{c}{ Variabel } & Koefisien Alpha Cronbach & Keterangan \\
\hline Kepatuhan Pajak (Y) & 0,816 & Reliabel \\
Sosialisasi Perpajakan (X1) & 0,800 & Reliabel \\
Kualitas Pelayanan (X2) & 0,766 & Reliabel \\
Sanksi Perpajakan (X3) & 0,808 & Reliabel \\
Biaya Kepatuhan (X4) & 0,805 & Reliabel \\
\hline Sumber: Data diolah, 2018 & &
\end{tabular}

Berdasarkan hasil uji reliabilitas yang disajikan dalam Tabel 5 dapat disimpulkan bahwa variabel-variabel yang digunakan dalam penelitian ini adalah reliabel dan layak digunakan menjadi alat ukur instrumen kuesioner dalam penelitian ini karena nilai Cronbach's Alpa dari keseluruhan variabel lebih besar dari 0,60 .

Uji Normalitas bertujuan untuk menguji apakah data telah berdistribusi normal atau tidak (Ghozali, 2016:30). Penentuan normal atau tidaknya distribusi 
Ni Komang Ayu Puspita Dewi danl Ketut Jati. Pengaruh ...

data dapat dilakukan pengujian dengan menggunakan statistik KolmogrovSmirnov. Hasil uji normalitas disajikan pada Tabel 6 berikut.

Tabel 6.

Hasil Uji Normalitas

\begin{tabular}{lr}
\hline & Unstandardized Residual \\
\hline $\mathrm{N}$ & 100 \\
Asymp. Sig. (2-tailed) & 0,912 \\
\hline Sumber: Data diolah, 2018 &
\end{tabular}

Berdasarkan Tabel 6hasil uji normalitas menunjukkan bahwa nilai signifikansi tersebut sebesar 0,912 . Hal tersebut berarti bahwa data berdistribusi normal karena nilai Asymp. Sig. lebih besar dari 0,05.

Uji multikolinearitas memiliki tujuan apakah terdapat korelasi antar variabel bebas atau tidak pada model regresi tersebut. Jika nilai tolerance lebih besar dari 0,10 atau nilai VIF lebih kecil dari 10, maka dapat dikatakan bahwa model regresi tidak terjadi multikolinearitas. Pada uji multikolinearitas ini mendapatkan hasil yang disajikan pada Tabel 7 berikut.

Tabel 7.

Hasil Uji Multikolinearitas

\begin{tabular}{lcrl}
\hline \multirow{2}{*}{ Variabel } & \multicolumn{2}{c}{ Collinearity Statistics } & \\
\cline { 2 - 3 } & Tolerance & VIF & \\
\hline 1 (Constant) & & & \\
Sosialisasi Perpajakan (X1) & 0,976 & 1,976 & Bebas multikolinearitas \\
Kualitas Pelayanan (X2) & 0,749 & 1,749 & Bebas multikolinearitas \\
Sanksi Perpajakan (X3) & 0,766 & 1,766 & Bebas multikolinearitas \\
Biaya Kepatuhan (X4) & 0,99 & 1,01 & Bebas multikolinearitas \\
\hline Sumber: Data diolah, 2018 & & &
\end{tabular}

Uji Multikolinearitas pada Tabel 7 mendapatkan hasil yang menunjukkan bahwa variabel bebas dalam model rergresi tidak saling berkorelasi. Masingmasing variabel memperoleh nilai tolerancelebih besar dari 0,10 dan memperoleh nilai VIF lebih kecil dari 10 . Hal ini menunjukkan bahwa kesimpulannya tidak 
terdapat masalah multikolinearitas karena tidak ada korelasi antar sesama variabel bebas dalam model regresi.

Uji heteroskedastisitas bertujuan untuk menguji apakah dalam model regresi tidak terjadi kesamaan varian dari residual satu pengamatan ke pengamatan yang lain (Ghozali, 2016:138). Model regresi tidak mengandung heteroskedastisitas jika nilai signifikansi variabel bebasnya lebih besar dari $\alpha=0,05$. Hasil uji heteroskedastisitas disajikan pada Tabel 8 sebagai berikut.

Tabel 8.

Hasil Uji Heteroskedastisitas

\begin{tabular}{lrrrrr}
\hline & \multicolumn{2}{c}{$\begin{array}{c}\text { Unstandardized } \\
\text { Coefficients }\end{array}$} & $\begin{array}{c}\text { Standardized } \\
\text { Coefficients }\end{array}$ & & \\
\cline { 2 - 4 } & \multicolumn{1}{c}{ B } & Std. Error & Beta & \multicolumn{1}{c}{ T } & \multicolumn{1}{c}{ Sig. } \\
\hline (Constant) & 0,577 & 0,880 & & 0,655 & 0,514 \\
Sosialisasi Perpajakan (X1) & $-0,012$ & 0,038 & 0,034 & $-0,324$ & 0,747 \\
Kualitas Pelayanan (X2) & 0,003 & 0,010 & 0,033 & 0,279 & 0,781 \\
Sanksi Perpajakan (X3) & $-0,005$ & 0,046 & $-0,012$ & $-0,101$ & 0,920 \\
Biaya Kepatuhan (X4) & 0,010 & 0,043 & 0,023 & 0,225 & 0,822 \\
\hline Sumber: Data diolah, 2018 & & & & &
\end{tabular}

Berdasarkan Tabel 8 menunjukkan bahwa model regresi tersebut tidak terjadi kesamaan varian atau bebas heteroskedastisitas karena mendapatkan hasil nilai signifikansi lebih besar dari 0,05 pada masing-masing variabel di model regresi.

Teknik analisis regresi linier berganda digunakan untuk mengetahui ketergantungan suatu variabel terikat terhadap satu atau lebih variabel bebas dengan atau tanpa variabel moderator. Hasil uji regresi linier berganda dapat dilihat pada Tabel 9 berikut. 
Tabel 9.

Hasil Analisis Regresi Linier Berganda

\begin{tabular}{|c|c|c|c|c|c|}
\hline \multirow[b]{2}{*}{ Model } & \multicolumn{2}{|c|}{$\begin{array}{c}\text { Unstandardized } \\
\text { Coefficients }\end{array}$} & \multirow{2}{*}{$\begin{array}{c}\begin{array}{c}\text { Standardized } \\
\text { Coefficients }\end{array} \\
\text { Beta } \\
\end{array}$} & \multirow[b]{2}{*}{$\mathbf{t}$} & \multirow[b]{2}{*}{ Sig. } \\
\hline & $\mathbf{B}$ & Std. Error & & & \\
\hline 1 (Constant) & 3,575 & 1,456 & & 2,456 & 0,016 \\
\hline Sosialisasi Perpajakan (X1) & 0,133 & 0,062 & 0,173 & 2,129 & 0,036 \\
\hline Kualitas Pelayanan (X2) & 0,067 & 0,016 & 0,388 & 4,179 & 0,000 \\
\hline Sanksi Perpajakan (X3) & 0,195 & 0,075 & 0,237 & 2,586 & 0,011 \\
\hline Biaya Kepatuhan (X4) & $-0,150$ & 0,071 & $-0,170$ & $-2,110$ & 0,037 \\
\hline Adjusted $R^{2}=0,361$ & & & & & \\
\hline$=13,008$ & & & & & \\
\hline $\mathrm{F}_{\text {signifikansi }}=0,000$ & & & & & \\
\hline
\end{tabular}

Pada hasil analisis regresi linier berganda tersebut maka dapat dibuat persamaan regresi sebagai berikut.

$$
\mathrm{Y}=3,575+0,133 \mathrm{X} 1+0,067 \mathrm{X} 2+0,195 \mathrm{X} 3-0,150 \mathrm{X} 4+\mathrm{e}
$$

Berdasarkan Tabel 9 nilai konstanta sebesar 3,575 memberikan arti bahwa jika variabel-variabel bebas sosialisasi perpajakan $\left(\mathrm{X}_{1}\right)$, kualitas pelayanan $\left(\mathrm{X}_{2}\right)$, sanksi perpajakan $\left(\mathrm{X}_{3}\right)$ dan biaya kepatuhan $\left(\mathrm{X}_{4}\right)$ diasumsikan konstan (tidak terjadi perubahan) maka nilai $\mathrm{Y}$ (kepatuhan wajib pajak) sebesar 3,575 satuan.Nilai koefisien regresi sosialisasi perpajakan $\left(\mathrm{X}_{1}\right)=0,133$ memberikan arti bahwa antara sosialisasi perpajakan $\left(\mathrm{X}_{1}\right)$ pada kepatuhan wajib pajak kendaraan bermotor (Y) terdapat pengaruh positifsebesar 0,133. Jadi jika sosialisasi perpajakan $\left(\mathrm{X}_{1}\right)$ naik sebesar satu satuan sedangkan kualitas pelayanan $\left(\mathrm{X}_{2}\right)$, sanksi perpajakan $\left(\mathrm{X}_{3}\right)$ dan biaya kepatuhan $\left(\mathrm{X}_{4}\right)$ diasumsikan tetap, maka kepatuhan wajib pajak kendaraan bermotor akan meningkat sebesar 0,133 satuan.Nilai koefisien regresi kualitas pelayanan $\left(\mathrm{X}_{2}\right)=0,067$ artinya antara variabel kualitas pelayanan $\left(\mathrm{X}_{2}\right)$ pada variabel kepatuhan wajib pajak kendaraan bermotor (Y) berpengaruh positif sebesar 0,067. Hal ini memiliki artijika kualitas pelayanan $\left(\mathrm{X}_{2}\right)$ terjadi peningkatan sebesar satu satuan sedangkan sosialisasi 
perpajakan $\left(\mathrm{X}_{1}\right)$, sanksi perpajakan $\left(\mathrm{X}_{3}\right)$ serta biaya kepatuhan $\left(\mathrm{X}_{4}\right)$ diasumsikan tetap, kepatuhan wajib pajak kendaraan bermotor akan naik sebesar 0,067 satuan.Nilai koefisien regresi sanksi perpajakan $\left(X_{3}\right)=0,195$ memiliki arti bahwa antara variabel sanksi perpajakan $\left(\mathrm{X}_{3}\right)$ pada variabel kepatuhan wajib pajak kendaraan bermotor $(\mathrm{Y})$ terdapat pengaruh positif sebesar 0,195. Artinya apabila sanksi perpajakan $\left(\mathrm{X}_{3}\right)$ terjadi peningkatan sebesar satu satuan sedangkan sosialisasi perpajakan $\left(\mathrm{X}_{1}\right)$, kualitas pelayanan $\left(\mathrm{X}_{2}\right)$ dan biaya kepatuhan $\left(\mathrm{X}_{4}\right)$ diasumsikan tetap, maka terjadi peningkatan pada kepatuhan wajib pajak kendaraan bermotor akan sebesar 0,195 satuan.Nilai koefisien regresi biaya kepatuhan $\left(\mathrm{X}_{4}\right)=-0,150$ memiliki arti adanya pengaruh negatif antara variabel biaya kepatuhan $\left(\mathrm{X}_{4}\right)$ pada variabel kepatuhan wajib pajak kendaraan bermotor (Y) sebesar 0,150. Hal ini memiliki arti jika biaya kepatuhan $\left(\mathrm{X}_{4}\right)$ mengalami peningkatan sebesar satu satuan sedangkan sosialisasi perpajakan $\left(\mathrm{X}_{1}\right)$, kualitas pelayanan $\left(\mathrm{X}_{2}\right)$ dan sanksi perpajakan $\left(\mathrm{X}_{3}\right)$ diasumsikan tetap, maka akan terjadi penurunan sebesar 0,150 satuanpada kepatuhan wajib pajak kendaraan bermotor akan menurun.

Hasil yang didapat pada analisis di Tabel 9 mendapatkan nilai Adjusted $R^{2}$ sebesar 0,361 yang memiliki arti36,1 persen varia dari variabel kepatuhan wajib pajak bisa dijabarkan oleh variabel sosialisasi perpajakan, kualitas pelayanan, sanksi perpajakan, dan biaya kepatuhan, sedangkan sisanya sebesar 63,9 persen dijelaskan oleh faktor-faktor lain yang tidak dijelaskan dalam model. Pada penelitian ini juga didapat hasil uji kelayakan model atau uji $\mathrm{F}$ yangmendapatkan nilai $\mathrm{F}$ hitung yaitu 13,008 dengan nilai signifikansi0,000 lebih kecil dari 0,05, 
maka dapat dikatakan bahwa sosialisasi perpajakan, kualitas pelayanan, sanksi perpajakan dan biaya kepatuhan yang berupa variabel bebas pada penelitian ini memang layak dipergunakan untuk memperkirakan kepatuhan wajib pajak kendaraan bermotor yang berupa variabel terikat.

Pengaruh variabel terikat terhadap variabel bebas secara individu dapat diketahui apabila menggunakan uji hipotesis atau uji t.Pengujian hipotesis dapat dilihat dari signifikansi hasil uji t harus lebih kecil dari 0,05 atau $5 \%$. Pada Tabel 9 hasil dari uji t pengaruh variabel dependen denganmasing-masing variabel independen dapat dijelaskan sebagai berikut: hipotesis pertama $\left(\mathrm{H}_{1}\right)$ menunjukkan bahwa nilai sig $\mathrm{t}_{\text {hitung }}(0,036)<0,05$ yang berarti $\mathrm{H}_{1}$ diterima. Hal ini memberikan bukti bahwa variabel sosialisasi perpajakan berpengaruh positif pada tingkat kepatuhan wajib pajak dalam membayar Pajak Kendaraan Bermotor. Hipotesis kedua $\left(\mathrm{H}_{2}\right)$ pengaruh kualitas pelayanan pada tingkat kepatuhan wajib pajak dalam membayar Pajak Kendaraan Bermotor menunjukkan nilai sigt hitung $(0,000)$ $<0,05$ yang berarti $\mathrm{H}_{2}$ diterima. Hal ini memberikan bukti bahwa kualitas pelayanan memberikan pengaruh yang positif pada tingkat kepatuhan wajib pajak dalam membayar Pajak Kendaraan Bermotor.

Hipotesis ketiga $\left(\mathrm{H}_{3}\right)$ menunjukkan nilai sig $\mathrm{t}_{\text {hitung }}(0,011)<0,05$ yang memiliki arti bahwa $\mathrm{H}_{3}$ diterima. Hal ini memberikan arti bahwa sanksi perpajakan memberikan pengaruh yang positif pada tingkat kepatuhan wajib pajak dalam membayar Pajak Kendaraan Bermotor. Pada hipotesis keempat $\left(\mathrm{H}_{4}\right)$ menunjukkan nilai sig $\mathrm{t}_{\text {hitung }}(0,037)<0,05$ yang menyatakan bahwa $\mathrm{H}_{4}$ diterima. 
Hal ini memberikan arti bahwa biaya kepatuhan mempunyai berpengaruh negatif pada tingkat kepatuhan wajib pajak dalam Membayar Pajak Kendaraan Bermotor. Hasil uji statitsik menunjukkan bahwa hipotesis pertama $\left(\mathrm{H}_{1}\right)$ dapat diterima yaitu sosialisasi perpajakan pada tingkat kepatuhan wajib pajak dalam membayar Pajak Kendaraan Bermotor di Kantor Bersama SAMSAT Klungkungberpengaruh positif.Hasil dari penelitian ini sejalan dengan hasil penelitian yang telah dilakukan oleh Widnyani (2016) dan Cahyadi (2016) dimana informasi mengenai Pajak Kendaraan Bermotor penting diketahui oleh wajib pajak karena informasi tersebut dapat digunakan wajib pajak sebagai dasar untuk bertindak, mengambil keputusan dan untuk menentukan strategi sehubungan dengan hak dan kewajiban sebagai wajib pajak. Semakin sering dilakukannya sosialisasi mengenai Pajak Kendaraan Bermotor, maka akan wajib pajak akan semakin banyak mendapat informasi dan semakin paham mengenai Pajak Kendaraan Bermotor sehingga meningkatkan kepatuhan wajib Pajak Kendaraan Bermotor di Kota Klungkung.

Hasil uji statistik menunjukkan bahwa hipotesis kedua $\left(\mathrm{H}_{2}\right)$ diterima artinya variabel kualitas pelayanan pada tingkat kepatuhan wajib pajak dalam membayar Pajak Kendaraan Bermotor di Kantor Bersama SAMSAT Klungkungberpengaruh positif.Hasil yang didapat pada penelitian ini sejalan dengan hasil yangdiperoleh dari penelitian Megawangi (2016)dan Rusmayani (2017) dimana kualitas pelayanan yang baik dapat memberikan rasa puas kepada wajib pajak atas pelayanan yang diterima pada saat pembayaran Pajak Kendaraan Bermotor sehingga dapat meningkatkan kesadaran akan tanggungjawabnya sebagai wajib pajak untuk patuh dalam melaksanakan kewajiban perpajakannya yang pada 
akhirnya akan meningkatkan penerimaan daerah di sektor perpajakan khususnya Pajak Kendaraan Bermotor.

Berdasarkan hasil uji statistik menunjukkan bahwa hipotesis ketiga $\left(\mathrm{H}_{3}\right)$ dapat diterima yaitu sanksi perpajakan pada tingkat kepatuhan wajib pajak dalam membayar Pajak Kendaraan Bermotor di Kantor Bersama SAMSAT Klungkungberpengaruh positif dan signifikan.Hasil yang didapat penelitian ini sesuai dengan hasil yang diperoleh pada penelitian Kusuma (2016),dan Putra (2017) yang menyatakan sanksi perpajakan memiliki pengaruh positif dan signifikan pada tingkat kepatuhan wajib pajak. Agar wajib pajak tidak melalaikan kewajibannya untuk menaati peraturan perundang-undangan perpajakan maka sanksi perpajakan perlu diterapkan. Apabila penegakan sanksi perpajakan semakin meningkat maka tingkat kepatuhan wajib pajak dalam membayar Pajak Kendaraan Bermotor di Kota Klungkung semakin meningkat pula.

Berdasarkan uji statistik memberikan hasil bahwahipotesis keempat $\left(\mathrm{H}_{4}\right)$ dapat diterima yaitu biaya kepatuhan pada tingkat kepatuhan wajib pajak dalam membayar Pajak Kendaraan Bermotor di Kantor Bersama SAMSAT Klungkungberpengaruh negatif.Hasil yang didapat padapenelitian ini sesuai dengan hasil yang diperoleh pada penelitian Fuadi (2013) dan Susmita (2015) bahwa biaya kepatuhan pajak berpengaruh negatif pada tingkat kepatuhan wajib pajak. Wajib pajak yang patuh pada kewajiban perpajakannya memiliki harapan biaya kepatuhan yang besar yang harus dikeluarkan agar kewajiban perpajakannya terpenuhi dapat ditekan serendah mungkin.Wajib pajak enggan untuk membayar pajak apabila biaya kepatuhan yang harus dikeluarkan terlalu tinggi, hal ini 
membuat biaya kepatuhan dapat menjadi hal yang menghambat atau mendukung perilaku seseorang.

\section{SIMPULAN}

Berdasarkan hasil penelitian dan pembahasan, maka dapat ditarik simpulan sebagai berikut: Sosialisasi perpajakan pada tingkat kepatuhan wajib pajak kendaraan bermotorberpengaruh positif. Hal ini memberikan arti apabila sosialisasi perpajakan berjalan baik, maka akan meningkatkan kepatuhan wajib pajak kendaraan bermotor. Kualitas pelayanan memiliki pengaruh positif pada tingkat kepatuhan wajib pajak kendaraan bermotor. Hal ini memberikan arti bahwa apabila petugas kantor SAMSAT Klungkung memberikan kepuasan pelayanan yang terbaik kepada wajib pajak, maka kepatuhan wajib pajak dalam membayar Pajak Kendaraan Bermotor akan mengalami peningkatan pula.Sanksi perpajakan memiliki pengaruh positif pada tingkat kepatuhan wajib pajak kendaraan bermotor. Hal ini menunjukkan jika sanksi dari perpajakan yang dikenakan semakin berat, hal ini menyebabkan meningkatnya kepatuhan wajib pajak dalam membayar Pajak Kendaraan Bermotor.Biaya kepatuhan memiliki pengaruh negatif terhadap tingkat kepatuhan wajib pajak dalam membayar pajak kendaraan bermotor di Kantor Brersama SAMSAT Klungkung. Hal ini menunjukkan bahwa, semakin besar biaya kepatuhan yang dikeluarkanmaka akan menurunkan tingkat kepatuhan wajib pajak dalam membayar Pajak Kendaraan Bermotor.

Berdasarkan hasil pembahasan dan simpulan pada penelitian ini, maka saran yang dapat disampaikan yaitu Bagi Kantor Bersama SAMSAT Klungkung 
sebaiknya dapat lebih berperan aktif dalam mensosialisasikan tata cara pentingnya memenuhi kewajiban membayar pajak baik melalui media masa maupun media elektronik untuk meningkatkan pengetahuan wajib pajak yang selanjutnya akan dipergunakan untuk pembangunan daerah itu sendiri.Kantor Bersama SAMSAT Klungkung juga diharapkan ketegasan penerapan sanksi perpajakan bagi para wajib pajak dapat ditingkatkan dan harus sesuai dengan peraturan serta ketentuan perpajakan yang masih berlaku, sehingga para wajib pajak akan lebih mematuhi aturan dalam membayar Pajak Kendaraan Bermotor. Selain itu rasa nyaman wajib pajak dalam melaksanakan kewajiban dalam membayar pajak juga harus diperhatikan, yaitu dengan meningkatkan kualitas dari pelayanan yang diberikan oleh petugas pajak serta bertindak profesional dalam memberikan pelayanan kepada wajib pajak di Kantor Bersama SAMSAT Klungkung. Untuk mengantisipasi agar biaya kepatuhan tidak menjadi kendala wajib pajak maka diperlukan tambahan fasilitas seperti mesin fotocopy di area Kantor Bersama SAMSAT Klungkung agar dapat meminimalisir waktu yang diperlukan untuk melengkapi syarat syarat membayar PKB sehingga hal ini tidak menjadi kendala bagi wajib pajak dalam melakukan kewajibannya. Dengan demikian diharapkan wajib pajak akan melaksanakan kewajiban perpajakannya dengan baik. Bagi wajib pajak khususnya wajib pajak kendaraan bermotor diharapkan lebih sadar akan kewajibannya dalam membayar pajak untuk meningkatkan pendapat asli daerah (PAD). Diharapkanwajib pajakakan lebih sadar bahwa penerimaan pajak sangat penting karena digunakan untuk membiayai segala pengeluaran Negara dan dapat menopang pembangunan dalam meningkatkan kesejahteraan masyarakat, 
sehingga kesadaran parawajib pajak dalam melakukan kewajibannya dapat ditingkatkan. Wajib pajak juga sebaiknya aktif mencari tahu peraturan perpajakan khususnya Pajak Kendaraan Bermotor agar kedepannya wajib pajak tidak ada yang tidak tahu tentang aturan terbaru dan tata cara pelaksanaan kewajiban perpajakan.Penelitian selanjutnya diharapkan dapat menggunakan populasi pada lokasi yang berbeda, agar hasil penelitian dapat dibandingkan dengan penelitian sebelumnya dan dapat juga menambah variabel lain yang mungkin dapat berpengaruh pada kepatuhan wajib pajak kendaraan bermotor.

\section{REFERENSI}

Ajzen, Icek. 1991. The Theory of Planned Behavior. Organizational Behavior and Human Decision Processes, Vol 50, pp: 179-211.

Anggadewi, Anisa. 2015. Pengaruh Pemahaman Pajak dan Biaya Kepatuhan Terhadap Tingkat Kepatuhan Wajib Pajak (Survei pada KPP Pratama Bandung Karees). Skripsi Program Studi Akuntansi Fakultas Ekonomi Universitas Widyatama.

Anggraeni, Intan Yuningtyas. 2013. Faktor-Faktor yang Mempengaruhi Kepatuhan Wajib Pajak Terhadap Penerimaan Pajak Penghasilan pada Kantor Pelayanan Pajak Pratama Semarang Tengah Satu. Diponegoro Journal of Social and Politic.

Cahyadi, I Made Wahyu. 2016. Pengaruh Kesadaran, Sosialisasi, Akuntabilitas Pelayanan Publik dan Sanksi Perpajakan pada Kepatuhan Wajib Pajak Kendaraan Bermotor. E-Jurnal Akuntansi Universitas Udayana, 16 (3), hal: 2342-2373.

Chau, Gerald and Patrik Leung. 2009. A Critical Review of Fischer Tax Compliance Model: A Research Syntesis. Journal of Accounting and Taxation. 1 (2), pp: 34-40.

Dharma, G. 2014. Pengaruh Kesadaran Wajib Pajak, Sosialisasi Perpajakan, Kualitas Pelayanan Pada Kepatuhan Wajib Pajak. E-Jurnal Akuntansi Universitas Udayana, 6 (1), hal: 340-353. 
Efendi, Ragil Handayani, Zahrob ZA. 2015. Pengaruh Biaya Kepatuhan, Sanksi Perpajakan dan Kesadaran Wajib Pajak Terhadap Kepatuhan Wajib Pajak. Jurnal Administrasi Bisnis-Perpajakan, 5 (2).

Endaryanti, Ratih Novi. 2017. Pengaruh Kualitas Pelayanan, Sanksi Perpajakan, Biaya Kepatuhan Pajak, Penerapan E-Filling dan Pengetahuan Pajak Terhadap Kepatuhan Wajib Pajak. Skripsi Fakultas Ekonomi dan Bisnis Universitas Muhamadiyah Surakarta.

Febriyanti, Anak Agung Istri Inten dan Putu Ery Setiawan. 2017. Analisa AspekAspek Wajib Pajak sebagai Anteseden Kepatuhan Wajib Pajak Kendaraan Bermotor di Gianyar. E-Journal Akuntansi Universitas Udayana, 21 (2), hal. 996-1025.

Feld, Lars P \& Frey, Bruno S. 2002. Trust Breeds Trust : How Taxpayers are Treated Working Paper No 98. Institute fo Empiricial Research in Economics University of Zurich.

Franzoni, Luigi Alberto. 1998. Tax Evasion and Tax Compliance. Encyclopedia of Law and Economics.

Fuadi, Arabella Oentari dan Yenni Mangoting. 2013. Pengaruh Kualitas Pelayanan Petugas Pajak, Sanksi Perpajakan dan Biaya Kepatuhan Pajak Terhadap Kepatuhan Wajib Pajak UMKM. Tax \& Accounting Review, 1 (1), hal: 18-27.

Ghozali, Imam. 2016. Aplikasi Analisis Multivariate Dengan Program IBM SPSS 2.Edisi 8. Semarang: Badan Penerbit Universitas Diponegoro.

Irianingsih, Eka. 2015. Pengaruh Kesadaran Wajib Pajak, Pelayanan Fiskus dan Sanksi Administrasi Pajak Terhadap Kepatuhan Wajib Pajak dalam Membayar Pajak Kendaraan Bermotor. Skripsi Program Studi Akuntansi Fakultas Ekonomi Universitas PGRI Yogyakarta.

Kusuma, Kartika Candra. 2016. Pengaruh Kualitas Pelayanan Pajak,Pemahaman Peraturan Perpajakan serta Sanksi Perpajakan Terhadap Kepatuhan Wajib Pajak Orang Pribadi dalam Membayar Pajak Tahun 2014. Skripsi Fakultas Ekonomi Universitas Negeri Yogyakarta.

Megawangi, Cokorda Agung Meggy. 2016. Sosialisasi Perpajakan sebagai Pemoderasi Pengaruh Kesadaran Wajib Pajak dan Kualitas Pelayanan pada Kepatuhan Wajib Pajak Badan di Kantor Pelayanan Pajak Pratama Gianyar. Skripsi Fakultas Ekonomi dan Bisnis Universitas Udayana. 
Mustikasari, Elia. 2007. Kajian Empiris Tentang Kepatuhan Wajib Pajak Badan di Perusahaan Industri Pengolahan di Surabaya. Simposium Nasional Akuntansi X Makasar.

Novitasari, Rosalina. 2015. Pengaruh Kesadaran Wajib Pajak, Sosialisasi Perpajakan, Kualitas Pelayanan pada Kepatuhan Wajib Pajak di SAMSAT Semarang III. Skripsi Program Studi Akuntansi Universitas Dian Uswantoro Semarang.

Palda, Filip dan Jan Hanousek. 2002. Journal of Quality of Government Services and the Civic Duty to Pay Taxes in the Czech and Slovak Republics, and other Transition Countries.

Paramartha, I Putu Indra Pradnya. 2015. Pengaruh Kualitas pelayanan, Pengetahuan dan Sanksi Perpajakan pada Kepatuhan Wajib Pajak Badan di KPP Pratama Gianyar. Skripsi Program Studi Akuntansi Fakultas Ekonomi dan Bisnis Universitas Udayana.

Pranata, Putu Aditya dan Putu Ery Setiawan. 2015. Pengaruh Sanksi Perpajakan, Kualitas Pelayanan, dan Kewajiban Moral pada Kepatuhan Wajib Pajak. EJurnal Akuntansi Universitas Udayana, 10 (2), hal.456-473.

Putra, I Made Adi Dharma. 2017. Analisis Faktor-Faktor yang Mempengaruhi Kepatuhan Wajib Pajak Kendaraan Bermotor di Kantor Bersama SAMSAT Tabanan. E-Jurnal Akuntansi Universitas Udayana, 18 (1), hal.557-587.

Putri, Siswanto Amanda R.A dan I Ketut Jati. 2012. Faktor-Faktor yang Mempengaruhi Kepatuhan Wajib Pajak dalam Membayar Pajak Kendaraan Bermotor di Kantor SAMSAT Denpasar. Jurnal Akuntansi Fakultas Ekonomi dan Bisnis Universitas Udayana, 2 (3).

Rusmayani, Ni Made Lisa dan Ni Luh Supadmi. 2017. Pengaruh Sosialisasi, Pengetahuan, Sanksi Pelayanan pada Kepatuhan Wajib Pajak Kendaraan Bermotor. E-jurnal Akuntansi Universitas Udayana, 20 (1), h:173-201.

Sari, Vivi Yuliani dan Neri Susanti. 2013. Faktor-Faktor Yang Mempengaruhi Kepatuhan Wajib Pajak Dalam Membayar Pajak Kendaraan Bermotor (PKB). Skripsi Program Studi Akuntansi Fakultas Ekonomi Universitas Dehasen Bengkulu.

Senja, Sri Prasetyo W. 2015. Pengaruh Kewajiban Moral, Kualitas Pelayanan dan Sanksi Perpajakan Terhadap Kepatuhan Wajib Pajak dalam Membayar Pajak Kendaraan Bermotor di Kantor Bersama Samsat Kota Sawahlunto. Diploma Thesis Fakultas Ekonomi Universitas Andalas. 
Sucahyani, Ni Made Arum. 2017. Pengaruh Pengetahuan Perpajakan, Pelayanan Fiskus, Biaya Kepatuhan Pajak, dan Sanksi Perpajakan pada Kepatuhan Wajib Pajak dalam Membayar Pajak Hotel di Dinas Pendapatan Kabupaten Tabanan. Skripsi Program Studi Akutansi Fakultas Ekonomi dan Bisnis Universitas Udayana.

Sugiyono. 2017. Metode Penelitian Kuantitatif, Kualitatif Dan R\&D. Bandung: Alfabeta.

Susmita, Putu Rara. 2015. Pengaruh Kualitas Pelayanan, Sanksi Perpajakan, Biaya Kepatuhan Pajak, Dan Penerapan E-Filing Pada Kepatuhan Pelaporan Wajib Pajak Orang Pribadi Di Kantor Pelayanan Pajak Pratama Denpasar Timur. Skripsi Sarjana Jurusan Akuntansi pada Fakultas Ekonomi dan Bisnis Universitas Udayana.

Torgler, B. (2005). Direct Democracy and Tax Morale. European Journal of Political Economy, 21, pp: 525-531.

Trisnasari, Ayu Tut Sukma, Edy Sujana, dan Nyoman Trisna Herawati. 2017. Pengaruh Kesadaran Wajib Pajak, Sosialisasi Perpajakan, dan Pengetahuan Perpajakan Terhadap Kemauan Wajib Pajak dalam Mengikuti Program Tax Amnesty. E-jurnal Universitas Pendidikan Ganesha, 7 (1).

Widnyani, Ida Ayu Dewi dan Ketut Alit Suardana. 2016. Pengaruh Sosialisasi, Sanksi dan Persepsi Akuntabilitas Terhadap Kepatuhan Wajib Pajak Dalam Membayar Pajak Kendaraan Bermotor. E-Jurnal Akuntansi Universitas Udayana, 16 (3), h: 2176-2203. ISSN: 2302-8556.

Winerungan, Lidya Oktaviane. 2013. Sosialisasi Perpajakan, Pelayanan Fiskus dan Sanksi Perpajakan terhadap Kepatuhan WPOP di KPP Manado dan KPP Bitung. Jurnal EMBA, 1 (3), h: 960-970. 